Published in final edited form as:

Struct Heart. 2020 ; 4(4): 295-299. doi:10.1080/24748706.2020.1782549.

\title{
Can Clinical Predictive Models Identify Patients Who Should Not Receive TAVR? A Systematic Review
}

\author{
Benjamin S. Wessler, MD, MS ${ }^{a, b}$, Andrew R. Weintraub, MD ${ }^{a}$, James E. Udelson, MD ${ }^{a}$, David \\ M. Kent, MD, CM, MS

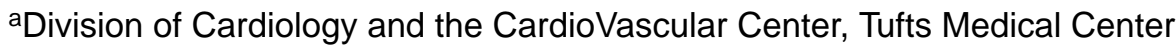 \\ bPredictive Analytics and Comparative Effectiveness (PACE) Center, Tufts Medical Center
}

\begin{abstract}
Background: One third of high- and prohibitive-risk TAVR patients remain severely symptomatic or die 1 year after treatment. There is interest in identifying individuals for whom this procedure is futile and should not be offered.

Methods: We performed a systematic review of the highest reported stratum of risk in TAVR clinical predictive models (CPMs). We explore whether currently available predictive models can identify patients for whom TAVR is futile, based on a quantitative futility definition and the observed and predicted outcomes for patients in the highest stratum of risk.

Results: 17 TAVR CPMs representing 69,191 treated patients were published from 2013 to 2018. When reported, the median number of patients in the highest stratum of risk was 569 (range 1 to 1759). Observed mortality for this risk stratum ranged from $9 \%$ at 30 days to $59 \%$ at 1 year after TAVR. Statistical confidence in these observed event rates was low. The highest predicted event rates ranged from $11.0 \%$ for in-hospital mortality to $75.1 \%$ for the composite of mortality or high symptom burden 1 year after TAVR.
\end{abstract}

Conclusion: No high-risk TAVR group in currently available TAVR CPMs had an appropriate event rate and adequate statistical power to meet a quantitative definition of futility.

\section{Keywords}

Clinical Cardiology; Interventional Cardiology; Non-invasive and minimally invasive Cardiology

\section{Introduction}

Recently, transcatheter aortic valve replacement (TAVR) has revolutionized the care of older adults with high operative risk or those previously considered inoperable, enabling treatment of symptomatic aortic stenosis where once there was none. ${ }^{1}$ While most patients benefit from TAVR, one third of high- and prohibitive-risk TAVR patients remain severely

\footnotetext{
Address for Correspondence: Benjamin S. Wessler, MD, FACC, Director, Heart Valve Center, Division of Cardiology, Assistant Professor of Medicine, Tufts University School of Medicine, bwessler@ tuftsmedicalcenter.org (617) 636-2273 F (617) 636-5913, Tufts Medical Center, 800 Washington Street, Box 63, Boston, MA 02111.

Disclosure statement: The authors have no conflicts of interest to report.
} 
symptomatic or die 1 year after treatment. ${ }^{2}$ Substantial work has focused on evaluating the hazard associated with various clinical factors ${ }^{3-10}$ in an effort to improve prediction, enhance shared decision-making, and identify patients who are unlikely to do well. There is an open question about whether these markers can be used to identify patients who do not benefit from TAVR. ${ }^{11}$ Single risk factors viewed in isolation are unlikely to effectively identify patients with extreme risk. Multivariable regression can more effectively riskstratify patients ${ }^{12}$ and might be able to identify patients for whom TAVR is futile.

TAVR can be offered to patients with extremely high predicted risk who are unlikely to do well. The question of whether TAVR should be offered to these patients is in some ways harder to answer. Given the resource-constrained realities of contemporary healthcare and the importance of delivering care that is concordant with patient's wishes, there is substantial interest in identifying individuals for whom this procedure is futile and should not be offered. ${ }^{11}$ This concept has been difficult to define because of the inherent valueladen nature of this idea and resulting lack of consensus about criteria and thresholds. A quantitative definition of futility, originally proposed by Scheinderman et al., ${ }^{13}$ attempted to use empirical evidence to anchor decisions about limiting treatments instead of opinion alone. This threshold was defined where "physicians [can] conclude (either through personal experience, experiences shared with colleagues or consideration of reported empiric data) that in the last 100 cases, a medical treatment has been useless, they should regard that treatment as futile". This quantitative definition has never been explored in the case of TAVR.

We recently reported on a systematic review of CPMs for patients with valvular heart disease (VHD). ${ }^{14}$ This work demonstrated that there are a number of CPMs that are available to predict outcomes for TAVR patients, though these models have not been widely tested in external validations and as a result there remain substantial uncertainties about TAVR predictions. Given the inherent methodological strengths of multivariable risk prediction, here we explore whether currently available TAVR CPMs can help identify patients for whom TAVR is futile, based on the oft-cited quantitative definition ${ }^{13}$ and the observed and predicted outcomes for the highest-risk patients.

\section{Materials and Methods}

\section{Systematic Review.}

The results of our systematic review have been previously reported. ${ }^{14}$ Briefly, we included data from the Tufts Predictive Analytics and Comparative Effectiveness (PACE) CPM Registry (www.pace.tuftsmedicalcenter.org/cpm), a database of predictive models for patients with cardiovascular disease. ${ }^{15}$ The methods for the Registry covering CPMs from January 1990 through 2015 have been previously published. The search terms used to identify CPMs are shown in the Supplemental Table. Here, we extended the PubMed search for TAVR CPMs to October $31^{\text {st }}$, 2018. Citations were reviewed to confirm completeness of our review. All data fields were extracted in duplicate to ensure accuracy. Discrepancies were discussed to arrive at consensus. For inclusion in this analysis, articles had to meet the following criteria: (1) develop a predictive model containing at least 2 predictors as a primary aim, (2) contain a model predicting the development of a clinical outcome following 
TAVR, and (3) present enough information to estimate the probability for an individual patient. Articles were excluded if they did not provide enough information to predict a patient's risk or if the described models predicted surrogate outcomes. Consistent with prior work, we excluded non- English reports, pharmacology reports, cost-effectiveness models, decision-analysis models, systematic reviews, and editorials.

\section{Definition of Futility:}

We use the quantitative definition of futility proposed by Scheinderman and colleagues. ${ }^{13}$ The statistical basis for this determination is that given 100 successive treatment failures for patients with a certain level of risk "the clinician can be $95 \%$ confident that no more than three successes would occur in every 100 comparable trials." Here, we explore whether a pre-procedure stratum of risk can be identified where at least 100 patients all die after being treated with TAVR. By using a statistical definition of this concept, the intent is to minimize reliance on value-laden concepts where consensus is unlikely to be achieved.

\section{Data Extraction:}

For each TAVR CPM we extracted information on predicted and observed outcome rates for the highest reported stratum of risk. This risk stratum was identified either as a pre-specified risk grouping or from an assessment of the highest risk quantile reported during assessment of model calibration. The $95 \%$ confidence interval (CI) for observed event rates in the risk stratum of interest was calculated using the exact binomial method. We compared the highest reported event rates to the quantitative definition of futility proposed by Schneiderman.

\section{Results}

17 TAVR CPMs representing 69,191 treated patients were published from 2013 to 2018 (Table 1). The median number of patients used to derive these predictions was 2137 (IQR 1488). These CPMs predict mortality $(\mathrm{N}=14)$ or the composite outcome of mortality or high symptom burden $(\mathrm{N}=3)$. Only one $\mathrm{CPM}^{16}$ has the stated goal of identifying procedural futility, defined as the composite of 1-year mortality, stroke, or lack of functional-class improvement and repeat admissions occurring $>1$ month after the procedure.

$13(76 \%)$ CPMs present risk information specific to the highest risk stratum. These risk estimates were most frequently identified by reviewing the $10^{\text {th }}$ decile of the HosmerLemeshow calibration plot $(\mathrm{N}=6) .9$ CPMs $(53 \%)$ did not present enough information to calculate a $\mathrm{CI}$ around the observed event rate. When reported, the median number of patients in the highest risk group was 569 (range 1 to 1759). The observed mortality rates in the highest risk group ranged from $9 \%(51 / 569 ; 95 \% \text { CI } 6.7 \% \text { to } 11.6 \%)^{17}$ to $100 \%(1 / 1$; CI $2.5 \%$ to $100 \%)^{18}$ for mortality at 30 days. Observed mortality at 1 year for the highest risk stratum ranged from $31 \%(237 / 763,95 \% \text { CI } 27 \% \text { to } 34 \%)^{17}$ to $59 \%(19 / 32,95 \%$ CI $41 \%$ to $76 \%)^{19}$. The highest predicted event rates rates ranged from $11.0 \%$ for in-hospital mortality ${ }^{20}$ to $75.1 \%$ for the composite of mortality or high symptom burden 1 year after $\mathrm{TAVR}^{21}$. Statistical confidence was lowest for the highest observed event rates (Figure 1). 
No high-risk TAVR group had an appropriate event rate and adequate statistical power to meet a quantitative definition of futility.

\section{Discussion}

The main finding from this study is that there is no evidence that aortic stenosis patients with little opportunity for benefit from TAVR can be identified ex ante. Review of the currently available evidence from TAVR CPMs demonstrate that these models cannot support a quantitative claim of futility for patients being considered for TAVR. Additionally, there is substantial uncertainty about outcomes for the highest risk patients, owing to the small number of patients included in these risk strata. ${ }^{22}$ Taken together, these data strongly suggest that providers cannot (and should not) look to extant predictive models alone to understand whether treatment with TAVR is futile.

There are certainly some patients with symptomatic aortic stenosis who should not be treated with TAVR. ${ }^{23}$ Procedural denial often results from an anticipated very low likelihood of benefit to either length of life or symptom improvement, though it is unrealistic to look toward CPM-based predictions to support such a claim. A recent expert consensus document suggested a Society of Thoracic Surgeons Predictive Risk of Mortality (STS-PROM) score > $15 \%$ be used as a threshold above which TAVR might be withheld ${ }^{23}$ based on a lack of appreciable benefit in all-cause mortality at 5 years in the PARTNER IB trial. ${ }^{24}$ We believe the rationale supporting this claim is flawed. First, STS-PROM discriminatory performance is substantially attenuated for patients receiving TAVR as it was not developed on these patients. ${ }^{14,25}$ Second, there were only 38 patients with STS-PROM $>15 \%$ in the TAVR treated arm of PARTNER IB and 6 were still alive at 5 years. As a result, using these data alone, it not possible to support a quantitative futility claim. Third, outcome rates from the original TAVR trials are likely not reflective of contemporary practice as devices and procedural techniques have improved over time leading to safer procedures and lower event rates. ${ }^{26}$ Lastly, it is clear that many patients pursue treatment with TAVR with the hope of improving symptoms ${ }^{27}$-a patient-centered goal that may be achieved in the absence of mortality benefit. Ultimately, in light of the available data, decisions for or against treatment for the highest risk patients must take a broader view.

Multidisciplinary heart team (MDT) decisions about the appropriateness of TAVR for the highest risk aortic stenosis patients should start with understanding procedural complexity and patient's goals of treatment. ${ }^{23,28}$ Efforts to enhance shared decision-making and understand the likelihood of achieving patient's goals should assume a central role. ${ }^{29}$ For the patients who are least likely to do well, a wider view of the MDT is appropriate, with inclusion of palliative care providers before treatment to more fully explore patient's goals, especially if TAVR is being considered primarily to improve symptoms. ${ }^{30}$ Ultimately, procedural denial may be most appropriate coming from the MDT (generally) as opposed to the operator (in isolation). ${ }^{11}$

There are limitations to this analysis. These TAVR CPMs overwhelmingly focus on mortality outcomes. As a result, improvements in symptoms are generally not accounted for. With the exception of a few CPMs, ${ }^{16,21}$ improvement in symptoms may be an acceptable 
outcome for many patients despite a lack of perceived mortality benefit. Another limitation to the presented data is that these CPMs are derived exclusively on patients who are treated with TAVR. In this analysis, there are no medically treated groups to compare outcome rates in the absence of TAVR though it is well known that mortality rates in untreated patients are extreme. ${ }^{31}$ Lastly, the quantitative definition of futility that is explored here may not be appropriate for TAVR decision-making, where health systems and providers may support pursuing treatment even for a very small chance of benefit (to either symptom burden or mortality).

\section{Conclusion}

In the case of TAVR, CPMs have assumed a central role in risk communication and have tremendous potential to enhance shared decision-making. However, currently available tools have insufficient statistical power to identify patients for whom TAVR is futile and there is substantial outcome uncertainty associated with these predictions for the highest risk patients. More work is needed to align the decision for or against treatment of the highestrisk individuals with patient-defined treatment goals.

\section{Supplementary Material}

Refer to Web version on PubMed Central for supplementary material.

\section{Acknowledgments}

Funding:

National Institutes of Health (R03 AG056447 GEMSSTAR Grant and K23 AG055667) and Bellows Foundation Grant from the American College of Cardiology.

\section{References:}

1. Leon MB, Smith CR, Mack M, Miller DC, Moses JW, Svensson LG, Tuzcu EM, Webb JG, Fontana GP, Makkar RR, Brown DL, Block PC, Guyton RA, Pichard AD, Bavaria JE, Herrmann HC, Douglas PS, Petersen JL, Akin JJ, Anderson WN, Wang D, Pocock S. Transcatheter aortic-valve implantation for aortic stenosis in patients who cannot undergo surgery. N Engl J Med. 2010;363:1597-1607. [PubMed: 20961243]

2. Holmes DR, Brennan JM, Rumsfeld JS, Dai D, O’Brien SM, Vemulapalli S, Edwards FH, Carroll J, Shahian D, Grover F, Tuzcu EM, Peterson ED, Brindis RG, Mack MJ, STS/ACC TVT Registry. Clinical outcomes at 1 year following transcatheter aortic valve replacement. JAMA. 2015;313:1019-28. [PubMed: 25756438]

3. Herrmann HC, Pibarot P, Hueter I, Gertz ZM, Stewart WJ, Kapadia S, Tuzcu EM, Babaliaros V, Thourani V, Szeto WY, Bavaria JE, Kodali S, Hahn RT, Williams M, Miller DC, Douglas PS, Leon MB. Predictors of mortality and outcomes of therapy in low-flow severe aortic stenosis: a Placement of Aortic Transcatheter Valves (PARTNER) trial analysis. Circulation. 2013;127:2316-26. [PubMed: 23661722]

4. Ribeiro HB, Lerakis S, Gilard M, Cavalcante JL, Makkar R, Herrmann HC, Windecker S, EnriquezSarano M, Cheema AN, Nombela-Franco L, Amat-Santos I, Muñoz-García AJ, Garcia Del Blanco B, Zajarias A, Lisko JC, Hayek S, Babaliaros V, Le Ven F, Gleason TG, Chakravarty T, Szeto WY, Clavel M-A, de Agustin A, Serra V, Schindler JT, Dahou A, Puri R, Pelletier-Beaumont E, Côté M, Pibarot P, Rodés-Cabau J. Transcatheter Aortic Valve Replacement in Patients With Low-Flow, Low-Gradient Aortic Stenosis: The TOPAS-TAVI Registry. J Am Coll Cardiol. 2018;71:1297-1308. [PubMed: 29566812] 
5. Toggweiler S, Boone RH, Rodés-Cabau J, Humphries KH, Lee M, Nombela-Franco L, Bagur R, Willson AB, Binder RK, Gurvitch R, Grewal J, Moss R, Munt B, Thompson CR, Freeman M, Ye J, Cheung A, Dumont E, Wood DA, Webb JG. Transcatheter Aortic Valve Replacement. J Am Coll Cardiol. 2012;59:2068-2074. [PubMed: 22483326]

6. Barbanti M, Binder RK, Dvir D, Tan J, Freeman M, Thompson CR, Cheung A, Wood DA, Leipsic J, Webb JG. Prevalence and impact of preoperative moderate/severe tricuspid regurgitation on patients undergoing transcatheter aortic valve replacement. Catheter Cardiovasc Interv. 2015;85:677-684. [PubMed: 24740834]

7. Dvir D, Waksman R, Barbash IM, Kodali SK, Svensson LG, Tuzcu EM, Xu K, Minha S, Alu MC, Szeto WY, Thourani VH, Makkar R, Kapadia S, Satler LF, Webb JG, Leon MB, Pichard AD. Outcomes of patients with chronic lung disease and severe aortic stenosis treated with transcatheter versus surgical aortic valve replacement or standard therapy: insights from the PARTNER trial (placement of AoRTic TraNscathetER Valve). J Am Coll Cardiol. 2014;63:269-79. [PubMed: 24140659]

8. Szerlip M, Zajarias A, Vemalapalli S, Brennan M, Dai D, Maniar H, Lindman BR, Brindis R, Carroll JD, Hamandi M, Edwards FH, Grover F, O'Brien S, Peterson E, Rumsfeld JS, Shahian D, Tuzcu EM, Holmes D, Thourani VH, Mack M. Transcatheter Aortic Valve Replacement in Patients With End-Stage Renal Disease. J Am Coll Cardiol. 2019;73:2806-2815. [PubMed: 31171086]

9. Sinning J-M, Ghanem A, Steinhäuser H, Adenauer V, Hammerstingl C, Nickenig G, Werner N. Renal function as predictor of mortality in patients after percutaneous transcatheter aortic valve implantation. JACC Cardiovasc Interv. 2010;3:1141-9. [PubMed: 21087750]

10. Alushi B, Beckhoff F, Leistner D, Franz M, Reinthaler M, Stähli BE, Morguet A, Figulla HR, Doenst T, Maisano F, Falk V, Landmesser U, Lauten A. Pulmonary Hypertension in Patients With Severe Aortic Stenosis: Prognostic Impact After Transcatheter Aortic Valve Replacement: Pulmonary Hypertension in Patients Undergoing TAVR. JACC Cardiovasc Imaging. 2019;12:591601. [PubMed: 29680341]

11. Lindman BR, Alexander KP, O'Gara PT, Afilalo J. Futility, Benefit, and Transcatheter Aortic Valve Replacement. JACC Cardiovasc Interv. 2014;7:707-716. [PubMed: 24954571]

12. Kent DM, Alsheikh-Ali A, Hayward R a Competing risk and heterogeneity of treatment effect in clinical trials. Trials. 2008;9:30. [PubMed: 18498644]

13. Schneiderman LJ, Jecker NS, Jonsen AR. Medical futility: its meaning and ethical implications. Ann Intern Med. 1990;112:949-54. [PubMed: 2187394]

14. Wessler BS, Lundquist CM, Koethe B, Park JG, Brown K, Williamson T, Ajlan M, Natto Z, Lutz JS, Paulus JK, Kent DM. Clinical Prediction Models for Valvular Heart Disease. J Am Heart Assoc. 2019;8:e011972.

15. Wessler BS, Paulus J, Lundquist CM, Ajlan M, Natto Z, Janes WA, Jethmalani N, Raman G, Lutz JS, Kent DM. Tufts PACE Clinical Predictive Model Registry: update 1990 through 2015. Diagnostic Progn Res. 2017;1:20.

16. Zusman O, Kornowski R, Witberg G, Lador A, Orvin K, Levi A, Assali A, Vaknin-Assa H, Sharony R, Shapira Y, Sagie A, Landes U. Transcatheter Aortic Valve Implantation Futility Risk Model Development and Validation Among Treated Patients With Aortic Stenosis. Am J Cardiol. 2017;120:2241-2246. [PubMed: 29037446]

17. Hermiller JB, Yakubov SJ, Reardon MJ, Deeb GM, Adams DH, Afilalo J, Huang J, Popma JJ, CoreValve United States Clinical Investigators. Predicting Early and Late Mortality After Transcatheter Aortic Valve Replacement. J Am Coll Cardiol. 2016;68:343-52. [PubMed: 27443429]

18. Iung B, Laouénan C, Himbert D, Eltchaninoff H, Chevreul K, Donzeau-Gouge P, Fajadet J, Leprince P, Leguerrier A, Lièvre M, Prat A, Teiger E, Laskar M, Vahanian A, Gilard M, FRANCE 2 Investigators. Predictive factors of early mortality after transcatheter aortic valve implantation: individual risk assessment using a simple score. Heart. 2014;100:1016-23. [PubMed: 24740804]

19. Lindman BR, Zajarias A, Maniar HS, Miller DC, Suri RM, Arnold S V, Webb J, Svensson LG, Kodali S, Xu K, Ayele GM, Lin F, Wong S-C, Babaliaros V, Thourani VH, Douglas PS, Lim S, Leon MB, Mack MJ. Risk stratification in patients with pulmonary hypertension undergoing transcatheter aortic valve replacement. Heart. 2015;101:1656-1664. [PubMed: 26264371] 
20. Edwards FH, Cohen DJ, O'Brien SM, Peterson ED, Mack MJ, Shahian DM, Grover FL, Tuzcu EM, Thourani VH, Carroll J, Brennan JM, Brindis RG, Rumsfeld J, Holmes DR. Development and Validation of a Risk Prediction Model for In-Hospital Mortality After Transcatheter Aortic Valve Replacement. JAMA Cardiol. 2016;1:46. [PubMed: 27437653]

21. Arnold S V, Reynolds MR, Lei Y, Magnuson EA, Kirtane AJ, Kodali SK, Zajarias A, Thourani VH, Green P, Rodés-Cabau J, Beohar N, Mack MJ, Leon MB, Cohen DJ, PARTNER Investigators. Predictors of poor outcomes after transcatheter aortic valve replacement: results from the PARTNER (Placement of Aortic Transcatheter Valve) trial. Circulation. 2014;129:2682-90. [PubMed: 24958751]

22. Gabbay E, Calvo-Broce J, Meyer KB, Trikalinos TA, Cohen J, Kent DM. The empirical basis for determinations of medical futility. J Gen Intern Med. 2010;25:1083-9. [PubMed: 20645019]

23. Bavaria JE, Tommaso CL, Brindis RG, Carroll JD, Deeb GM, Feldman TE, Gleason TG, Horlick EM, Kavinsky CJ, Kumbhani DJ, Miller DC, Seals AA, Shahian DM, Shemin RJ, Sundt TM, Thourani VH. 2018 AATS/ACC/SCAI/STS Expert Consensus Systems of Care Document: Operator and Institutional Recommendations and Requirements for Transcatheter Aortic Valve Replacement: A Joint Report of the American Association for Thoracic Surgery, American College of. J Am Coll Cardiol. 2019;73:340-374. [PubMed: 30031107]

24. Kapadia SR, Leon MB, Makkar RR, Tuzcu EM, Svensson LG, Kodali S, Webb JG, Mack MJ, Douglas PS, Thourani VH, Babaliaros VC, Herrmann HC, Szeto WY, Pichard AD, Williams MR, Fontana GP, Miller DC, Anderson WN, Akin JJ, Davidson MJ, Smith CR. 5-year outcomes of transcatheter aortic valve replacement compared with standard treatment for patients with inoperable aortic stenosis ( PARTNER 1 ): a randomised controlled trial. Lancet. 2015;6736:1-7.

25. Wendt D, Thielmann M, Kahlert P, Kastner S, Price V, Al-Rashid F, Patsalis P, Erbel R, Jakob H. Comparison between different risk scoring algorithms on isolated conventional or transcatheter aortic valve replacement. Ann Thorac Surg. 2014;97:796-802. [PubMed: 24594746]

26. Holmes DR, Nishimura RA, Grover FL, Brindis RG, Carroll JD, Edwards FH, Peterson ED, Rumsfeld JS, Shahian DM, Thourani VH, Tuzcu EM, Vemulapalli S, Hewitt K, Michaels J, Fitzgerald S, Mack MJ. Annual Outcomes With Transcatheter Valve Therapy. J Am Coll Cardiol. 2015;66:2813-2823. [PubMed: 26652232]

27. Arnold SV, Spertus JA, Vemulapalli S, Li Z, Matsouaka RA, Baron SJ, Vora AN, Mack MJ, Reynolds MR, Rumsfeld JS, Cohen DJ. Quality-of-Life Outcomes After Transcatheter Aortic Valve Replacement in an Unselected Population. JAMA Cardiol. 2017;64111.

28. Coylewright M, Mack MJ, Holmes DR, O'Gara PT. A call for an evidence-based approach to the Heart Team for patients with severe aortic stenosis. J Am Coll Cardiol. 2015;65:1472-80. [PubMed: 25857913]

29. Coylewright M, O’Neill E, Sherman A, Gerling M, Adam K, Xu K, Grande SW, Dauerman HL, Dodge SE, Sobti NK, Saunders CH, Schott SL, Elwyn G, Durand M. The Learning Curve for Shared Decision-making in Symptomatic Aortic Stenosis. JAMA Cardiol. 2020;03756:1-7.

30. Kirkpatrick JN, Hauptman PJ, Swetz KM, Blume ED, Gauvreau K, Maurer M, Goodlin SJ. Palliative Care for Patients With End-Stage Cardiovascular Disease and Devices: A Report From the Palliative Care Working Group of the Geriatrics Section of the American College of Cardiology. JAMA Intern Med. 2016;23-25.

31. Varadarajan P, Kapoor N, Bansal RC, Pai RG. Clinical Profile and Natural History of 453 Nonsurgically Managed Patients With Severe Aortic Stenosis. Ann Thorac Surg. 2006;82:21112115. [PubMed: 17126120]

32. Kotting J, Schiller W, Beckmann A, Schafer E, Dobler K, Hamm C, Veit C, Welz A. German Aortic Valve Score: a new scoring system for prediction of mortality related to aortic valve procedures in adults. Eur J Cardio-Thoracic Surg. 2013;43:971-977.

33. Capodanno D, Barbanti M, Tamburino C, D’Errigo P, Ranucci M, Santoro G, Santini F, Onorati F, Grossi C, Covello RD, Capranzano P, Rosato S, Seccareccia F, OBSERVANT Research Group. A simple risk tool (the OBSERVANT score) for prediction of 30-day mortality after transcatheter aortic valve replacement. Am J Cardiol. 2014;113:1851-8. [PubMed: 24837264]

34. D’Ascenzo F, Capodanno D, Tarantini G, Nijhoff F, Ciuca C, Rossi ML, Brambilla N, Barbanti M, Napodano M, Stella P, Saia F, Ferrante G, Tamburino C, Gasparetto V, Agostoni P, Marzocchi A, Presbitero P, Bedogni F, Cerrato E, Omedè P, Conrotto F, Salizzoni S, Biondi Zoccai G, Marra S, 
Rinaldi M, Gaita F, D’Amico M, Moretti C. Usefulness and validation of the survival posT TAVI score for survival after transcatheter aortic valve implantation for aortic stenosis. Am J Cardiol. 2014;114:1867-74. [PubMed: 25438915]

35. Debonnaire P, Fusini L, Wolterbeek R, Kamperidis V, van Rosendael P, van der Kley F, Katsanos S, Joyce E, Tamborini G, Muratori M, Gripari P, Bax JJ, Marsan NA, Pepi M, Delgado V. Value of the "TAVI2-SCORe" versus surgical risk scores for prediction of one year mortality in 511 patients who underwent transcatheter aortic valve implantation. Am J Cardiol. 2015;115:234-42. [PubMed: 25432413]

36. Forcillo J, Condado JF, Ko Y-A, Yuan M, Binongo JN, Ndubisi NM, Kelly JJ, Babaliaros V, Guyton RA, Devireddy C, Leshnower BG, Stewart JP, Perrault LP, Khairy P, Thourani VH. Assessment of Commonly Used Frailty Markers for High- and Extreme-Risk Patients Undergoing Transcatheter Aortic Valve Replacement. Ann Thorac Surg. 2017;104:1939-1946. [PubMed: 28942076]

37. Halkin A, Steinvil A, Witberg G, Barsheshet A, Barkagan M, Assali A, Segev A, Fefer P, Guetta V, Barbash IM, Kornowski R, Finkelstein A. Mortality prediction following transcatheter aortic valve replacement: A quantitative comparison of risk scores derived from populations treated with either surgical or percutaneous aortic valve replacement. The Israeli TAVR Registry Risk Model Accuracy A. Int J Cardiol. 2016;215:227-231. [PubMed: 27128536]

38. Martin GP, Sperrin M, Ludman PF, De Belder MA, Redwood SR, Townend JN, Gunning M, Moat NE, Banning AP, Buchan I, Mamas MA. Novel United Kingdom prognostic model for 30-day mortality following transcatheter aortic valve implantation. Heart. 2018;104:1109-1116. [PubMed: 29217636] 


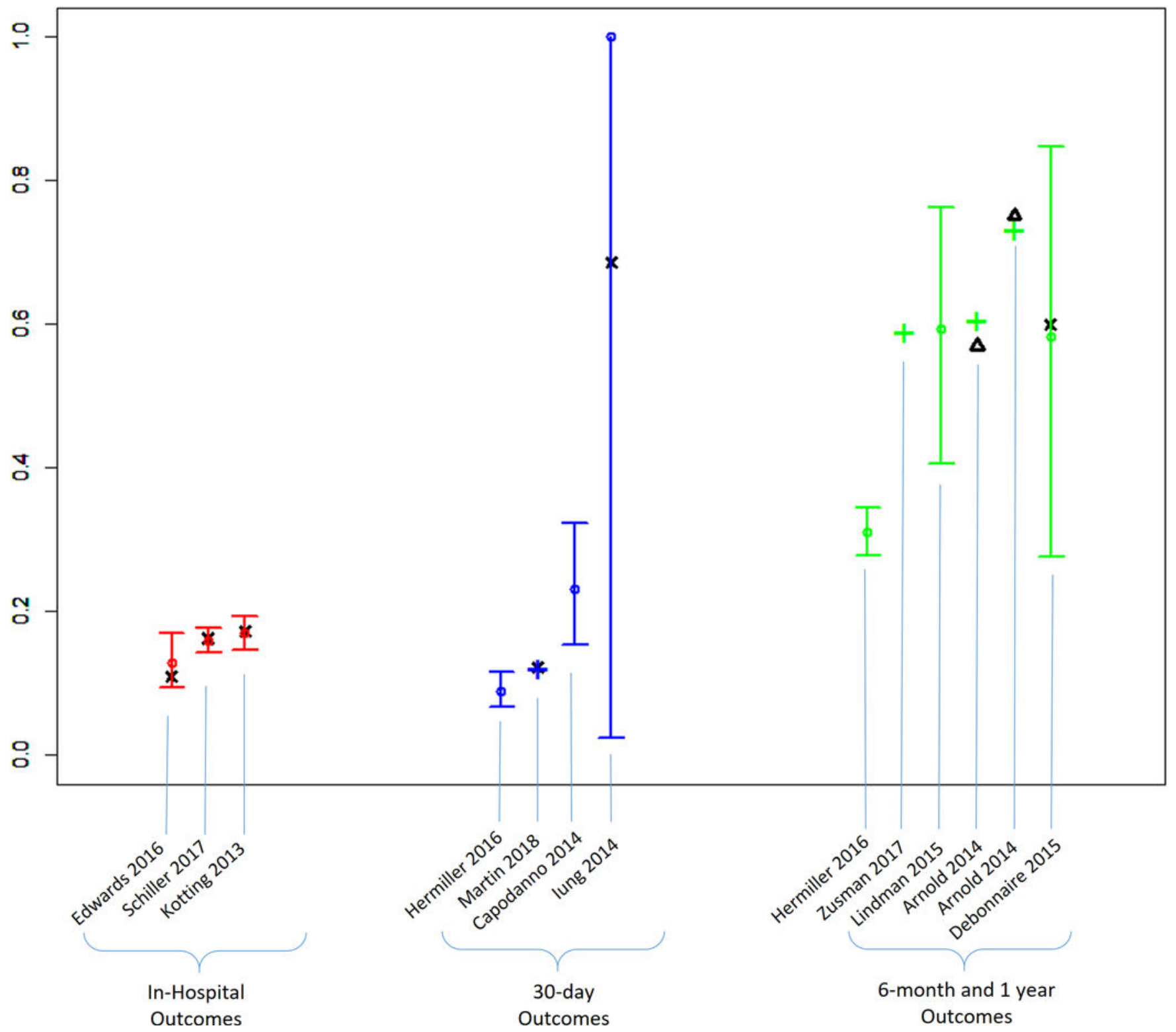

Figure 1.

Each of these 13 columns represents data from an individual TAVR CPM. The predicted and observed event rates for patients identified as the highest risk are depicted on the y-axis. Colors represent different time horizons, which are shown on the x-axis (In-hospital, 30 days, 6 months and 1 year). o represent observed event rates, error bars represent 95\% CI surrounding the observed event rates in the highest risk strata. + represent observed rates where no CI can be calculated. $\mathbf{x}$ represent predicted mortality rates. $\Delta$ represents predicted composite of mortality or high symptom burden. Not every column has complete information on observed and predicted data or confidence intervals, as most CPMs report incomplete data. 


\section{Table 1.}

\section{TAVR Clinical Predictive Models.}

Model $\mathrm{N}$ is total number of patients. Events represents total number of outcomes. Method represents regression method used. $\mathrm{N}$ Highest risk group indicates the number of patients in the highest risk quantile used for analysis.

\begin{tabular}{|c|c|c|c|c|c|c|c|c|c|c|c|}
\hline Author & Year & Outcome & $\begin{array}{c}\text { Model } \\
\mathbf{N}\end{array}$ & Events & Method & $\begin{array}{c}\text { C- } \\
\text { statistic }\end{array}$ & Risk Levels & $\begin{array}{c}\mathbf{N} \\
\text { Highest } \\
\text { risk } \\
\text { group }\end{array}$ & $\begin{array}{c}\text { Predicted } \\
\text { Risk } \\
\text { (high }\end{array}$ & $\begin{array}{c}\text { Observed } \\
\text { Risk } \\
\text { (high) }\end{array}$ & $\begin{array}{c}\text { Events } \\
\text { (high) }\end{array}$ \\
\hline Kotting $^{32}$ & 2013 & $\begin{array}{c}\text { in- } \\
\text { hospital } \\
\text { mortality }\end{array}$ & 11147 & 416 & $\begin{array}{l}\text { Logistic } \\
\text { regression }\end{array}$ & 0.81 & $\begin{array}{c}\text { Low, } \\
\text { moderate, } \\
\text { high }\end{array}$ & 1038 & 0.173 & 0.17 & 176 \\
\hline Arnold $^{21}$ & 2014 & $\begin{array}{l}\text { 6-month } \\
\text { poor } \\
\text { outcome }\end{array}$ & 2137 & 704 & $\begin{array}{l}\text { Logistic } \\
\text { regression }\end{array}$ & 0.66 & $\begin{array}{c}\text { Low } \\
(<25 \%), \\
\text { intermediate } \\
(25 \% \text { to } \\
<50 \%), \\
\text { high } \\
(>50 \%)\end{array}$ & - & 0.57 & 0.61 & NR \\
\hline Arnold $^{21}$ & 2014 & $\begin{array}{c}1 \text {-year } \\
\text { poor } \\
\text { outcome }\end{array}$ & 2130 & 1073 & $\begin{array}{l}\text { Logistic } \\
\text { regression }\end{array}$ & 0.66 & $\begin{array}{c}\text { Low } \\
(<25 \%), \\
\text { intermediate } \\
(25 \% \text { to } \\
<50 \%), \\
\text { high }(50 \% \\
\text { to }<70 \%) \text {, } \\
\text { very high } \\
(>70 \%)\end{array}$ & - & 0.75 & 0.73 & NR \\
\hline Capodanno $^{33}$ & 2014 & $\begin{array}{l}30 \text { day } \\
\text { mortality }\end{array}$ & 1256 & 77 & $\begin{array}{l}\text { Logistic } \\
\text { regression }\end{array}$ & 0.73 & $\begin{array}{l}\text { Low, } \\
\text { medium, } \\
\text { high }\end{array}$ & 104 & - & 0.23 & 24 \\
\hline D'Ascenzo ${ }^{34}$ & 2014 & $\begin{array}{l}30 \text { day } \\
\text { mortality }\end{array}$ & 1064 & 60 & $\begin{array}{l}\text { Logistic } \\
\text { regression }\end{array}$ & 0.66 & - & - & - & - & NR \\
\hline D'Ascenzo $^{34}$ & 2014 & $\begin{array}{l}1 \text { year } \\
\text { mortality }\end{array}$ & 1064 & 165 & $\begin{array}{l}\text { Logistic } \\
\text { regression }\end{array}$ & 0.68 & - & - & - & - & NR \\
\hline Iung ${ }^{18}$ & 2014 & $\begin{array}{l}30 \text { day } \\
\text { mortality }\end{array}$ & 2552 & 253 & $\begin{array}{l}\text { Logistic } \\
\text { regression }\end{array}$ & 0.67 & - & 1 & 0.69 & 1 & 1 \\
\hline Debonnaire $^{35}$ & 2015 & $\begin{array}{l}1 \text { year } \\
\text { mortality }\end{array}$ & 509 & 80 & $\begin{array}{c}\text { Cox } \\
\text { regression }\end{array}$ & 0.715 & $\begin{array}{c}\text { Low }(<3 \\
\text { pts }), \text { high } \\
(>3 \text { pts })\end{array}$ & 12 & 0.60 & 0.58 & 7 \\
\hline Edwards $^{20}$ & 2016 & $\begin{array}{c}\text { in- } \\
\text { hospital } \\
\text { mortality }\end{array}$ & 13672 & 730 & $\begin{array}{l}\text { Logistic } \\
\text { regression }\end{array}$ & 0.67 & - & - & 0.11 & 0.13 & NR \\
\hline Schiller $^{32}$ & 2017 & $\begin{array}{c}\text { in- } \\
\text { hospital } \\
\text { mortality }\end{array}$ & 18054 & 817 & $\begin{array}{l}\text { Logistic } \\
\text { regression }\end{array}$ & 0.74 & - & 1759 & 0.16 & 0.16 & 281 \\
\hline Forcillo $^{36}$ & 2017 & $\begin{array}{l}\text { 30-day } \\
\text { mortality }\end{array}$ & 361 & 21 & $\begin{array}{l}\text { Logistic } \\
\text { regression }\end{array}$ & 0.74 & - & - & - & - & NR \\
\hline Zusman $^{16}$ & 2017 & $\begin{array}{l}\text { procedural } \\
\text { futility }{ }^{+}\end{array}$ & 435 & 66 & $\begin{array}{l}\text { Logistic } \\
\text { regression }\end{array}$ & 0.73 & $\begin{array}{l}\text { Low, } \\
\text { medium, } \\
\text { high }\end{array}$ & - & - & 0.59 & NR \\
\hline Hermiller $^{17}$ & 2016 & 30-day & 2482 & 144 & $\begin{array}{c}\text { Cox } \\
\text { regression }\end{array}$ & 0.76 & $\begin{array}{l}\text { Low (Q1), } \\
\text { moderate } \\
\text { (Q2, Q3), } \\
\text { high (Q4) }\end{array}$ & 569 & - & 0.09 & 51 \\
\hline Hermiller $^{17}$ & 2016 & $\begin{array}{l}\text { 1-year all- } \\
\text { cause } \\
\text { death }\end{array}$ & 2482 & 566 & $\begin{array}{c}\text { Cox } \\
\text { regression }\end{array}$ & 0.83 & $\begin{array}{l}\text { Low (Q1), } \\
\text { moderate } \\
\text { (Q2, Q3), } \\
\text { high (Q4) }\end{array}$ & 763 & - & 0.31 & 237 \\
\hline
\end{tabular}




\begin{tabular}{|c|c|c|c|c|c|c|c|c|c|c|c|}
\hline Author & Year & Outcome & $\begin{array}{c}\text { Model } \\
\mathbf{N}\end{array}$ & Events & Method & $\begin{array}{c}\text { C- } \\
\text { statistic }\end{array}$ & Risk Levels & $\begin{array}{c}\mathbf{N} \\
\text { Highest } \\
\text { risk } \\
\text { group }\end{array}$ & $\begin{array}{c}\text { Predicted } \\
\text { Risk } \\
\text { (high }\end{array}$ & $\begin{array}{c}\text { Observed } \\
\text { Risk } \\
\text { (high) }\end{array}$ & $\begin{array}{c}\text { Events } \\
\text { (high) }\end{array}$ \\
\hline Halkin $^{37}$ & 2016 & $\begin{array}{c}\text { 30-day } \\
\text { mortality }\end{array}$ & 1327 & 45 & $\begin{array}{l}\text { Logistic } \\
\text { regression }\end{array}$ & 0.63 & - & - & - & - & NR \\
\hline Lindman $^{19}$ & 2015 & $\begin{array}{l}\text { 1-year all- } \\
\text { cause } \\
\text { mortality }\end{array}$ & 2180 & 471 & $\begin{array}{c}\text { Cox } \\
\text { regression }\end{array}$ & 0.65 & $\begin{array}{l}\text { Score } 0-1, \\
2-3,4-5, \geq \\
6\end{array}$ & 32 & - & 0.59 & 19 \\
\hline Martin $^{38}$ & 2018 & $\begin{array}{l}\text { 30-day } \\
\text { mortality }\end{array}$ & 6339 & 326 & $\begin{array}{l}\text { Logistic } \\
\text { regression }\end{array}$ & 0.66 & - & - & 12.3 & 12.1 & NR \\
\hline
\end{tabular}

